\title{
Hemichorea-hemiballism as the presenting manifestation of diabetes mellitus
}

\author{
Rajesh Verma, Heramba Narayan Praharaj
}

Department of Neurology, King George Medical University, Lucknow, Uttar Pradesh, India

\section{Correspondence to} Professor Rajesh Verma, drrajeshverma32@yahoo.com

\section{DESCRIPTION}

A 70-year-old woman presented with a history of acute onset abnormal movements of left half of the body for the previous 2 days. The movements were rapid, jerky, non-rhythmic present through out the day and were not associated with loss of consciousness, tongue bite, urinary incontinence. There was no history of fever, headache, nausea or vomiting associated with the movements. There was no previous history of diabetes mellitus, hypertension, tuberculosis, trauma or epilepsy in the past.

General examination revealed no abnormality except for bilateral xanthelasma. Higher mental function and cranial nerve examinations were normal. There was no weakness of limbs. There was no sensory loss and meningeal signs were negative.

There were abnormal movements restricted to left half of the body. They were choreiform in nature with some ballistic component, both proximal and distal in upper limb and lower limb (more intense in the former), also involved the head (video 1). The patient was completely unable to execute any voluntary movements in the left upper limb because of the movements. The patient was alert while she was exhibiting involuntary movement.

Routine hemogram was normal. Serum sodium, potassium, calcium, urea and creatine were 140 ,

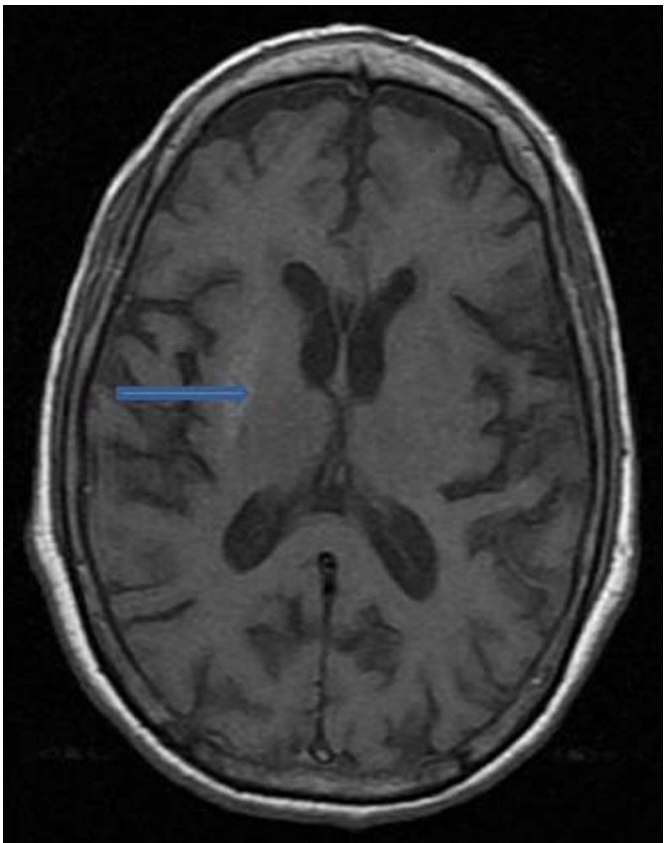

Figure 1 MRI, T1-weighted image revealed hyperintense signal changes in right putamen region.

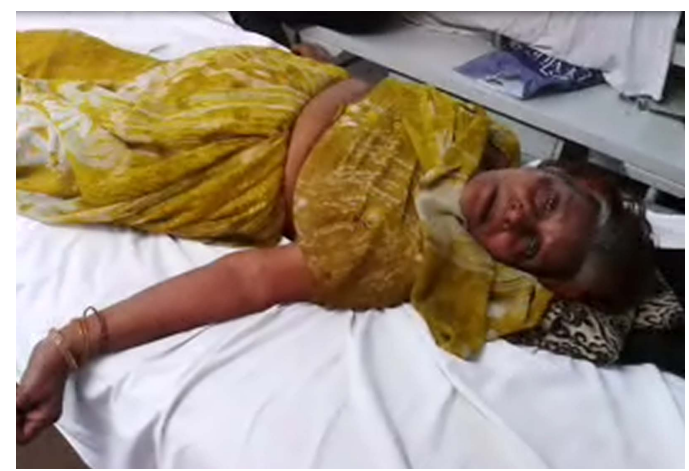

Video 1 Video of the patient demonstrating hemichorea-hemiballism on left side. The patient was alert while she was exhibiting involuntary movement.

$3.5,1.2 \mathrm{mmol} / \mathrm{L}, 25,0.5 \mathrm{mg} / \mathrm{dL}$, respectively. Liver function test, lipid profile and thyroid function tests were normal. The blood sugar at admission was $305 \mathrm{mg} / \mathrm{dL}(234 \mathrm{mg} / \mathrm{dL}$ on a repeat sample performed $6 \mathrm{~h}$ later after treatment) Urine was negative for ketone bodies.

An MRI of the brain revealed T1 hyperintensity of right putamen without any clear signal changes on T2 or fluid-attenuated inversion recovery sequences (figure 1). The presence of hyperglycaemia and T1 hyperintensity in the right putamen with left hemichorea suggest the diagnosis of diabetic hemichorea-hemiballism The meticulous control of diabetes with clonezepam $(0.5 \mathrm{mg}$ thrice daily) led to complete disappearance of abnormal movements within 1 week (video 2).

Chorea is a type of hyperkinetic movement disorder characterised by non-rhythmic, rapid jerky, non-repetitive, flowing involuntary movements. When severe, it involves proximal part of limbs

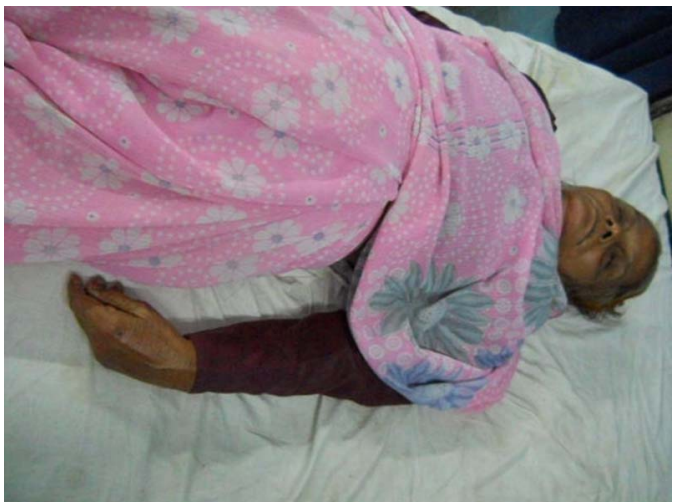

Video 2 The disappearance of involuntary movements after control of hyperglycemia. 


\section{Learning points}

- Chorea is a hyperkinetic movement disorder caused by multiple disorders.

- The initial presentation of hemichorea-hemiballism in elderly patients should raise the suspicion of undetected hyperglycaemia.

- Diabetic chorea is a well treatable clinical disorder with early control of blood sugar.

and causes flinging type of movement (chorea-ballism). The causes are multiple which include metabolic, rheumatic, immune mediated, neurodegenerative, vascular, infections, drugs, trauma, toxins and structural abnormalities in striatal region. ${ }^{1}$
In our patient, the hemichorea-hemiballism was the initial manifestation of diabetes. There are some case reports which described the hyperglycaemia causing chorea. The mechanism is poorly understood, however shift to anaerobic metabolism, cellular dysfunction or direct hyperglycaemic insults to striatum are proposed factors. ${ }^{2}$

Contributors RV came up with the concept and idea of writing the case report. HNP assisted in writing the manuscript for the case report.

Competing interests None.

Patient consent Obtained.

Provenance and peer review Not commissioned; externally peer reviewed.

\section{REFERENCES}

1 Hsu JL, Wang HC, Hsu WC. Hyperglycemia-induced unilateral basal ganglion lesions with and without hemichorea. A PET study. J Neurol 2004;251:1486-90.

2 Lin JJ, Chang MK. Hemiballism-hemichorea and nonketotic hyperglycemia. J Neurol Neurosurg Psychiatry 1994;57:748-50.

Copyright 2013 BMJ Publishing Group. All rights reserved. For permission to reuse any of this content visit

http://group.bmj.com/group/rights-licensing/permissions.

BMJ Case Report Fellows may re-use this article for personal use and teaching without any further permission.

Become a Fellow of BMJ Case Reports today and you can:

- Submit as many cases as you like

- Enjoy fast sympathetic peer review and rapid publication of accepted articles

- Access all the published articles

- Re-use any of the published material for personal use and teaching without further permission

For information on Institutional Fellowships contact consortiasales@bmjgroup.com

Visit casereports.bmj.com for more articles like this and to become a Fellow 